\title{
Low abundance plasma proteins in labour
}

\author{
Wei Yuan ${ }^{1,2,3}$, Kate Heesom ${ }^{4}$, Robert Phillips ${ }^{1}$, Lina Chen ${ }^{5}$, Jo Trinder ${ }^{6}$ and Andrés López Bernal ${ }^{1,6}$ \\ ${ }^{1}$ School of Clinical Sciences, University of Bristol, Dorothy Hodgkin Building, Whitson Street, Bristol BS1 3NY, UK, \\ ${ }^{2}$ The Wellcome Trust Centre for Human Genetics, University of Oxford, Roosevelt Drive, Oxford OX3 $7 B N$, UK, \\ ${ }^{3}$ Department of Twin Research and Genetic Epidemiology, King's College London, St Thomas' Hospital Campus, \\ 1 st Floor South Wing Block 4, Westminster Bridge Road, London SE1 7EH, UK, ${ }^{4}$ University of Bristol Proteomics \\ Facility, University of Bristol, Medical Sciences Building, University Walk, Bristol BS8 1TD, UK, ${ }^{5}$ The Cancer Genome \\ Project, Wellcome Trust Sanger Institute, Hinxton, Cambridge CB10 1SA, UK and ${ }^{6}$ Department of Obstetrics and \\ Gynaecology, St Michael's Hospital, Southwell Street, Bristol BS2 8EG, UK
}

Correspondence should be addressed to A López Bernal at School of Clinical Sciences, University of Bristol;

Email: a.lopezbernal@bris.ac.uk

\begin{abstract}
Every year, millions of births worldwide are complicated by prematurity or difficult post-term deliveries, resulting in a high incidence of perinatal mortality and morbidity. Our poor understanding of human parturition is a key reason for our inability to improve the management of preterm and post-term birth. In this study, we used proteomic techniques to look into protein changes in placental blood plasma obtained from women before or after spontaneous or induced labour, with vaginal or caesarean section deliveries. Our aim was to understand the basic mechanisms of human parturition regardless of whether the signals that trigger labour are of maternal and/or fetal origin. We found proteins from 33 genes with significantly altered expression profiles in relation to mode of labour and delivery. Most changes in labour occurred in proteins associated with 'immune and defence responses'. Although the signal transduction and regulation of these pathways varied among modes of delivery, hepatocyte nuclear factor 1 homeobox A emerged as a shared protein in the mechanism of labour. Moreover, several apolipoproteins such as apolipoprotein A-IV and APOE were found to change with labour, and these changes were also confirmed in maternal plasma. This study has identified significant protein changes in placental intervillous plasma with labour and has revealed several pathways related to human parturition.

Reproduction (2012) $\mathbf{1 4 4}$ 505-518
\end{abstract}

\section{Introduction}

Deliveries at or around term are crucial, not only for the well-being of women and newborns but also to reduce the cost to health services from medical complications arising from alterations in the timing of birth. However, about $8 \%$ of pregnant women have an indicated or spontaneous preterm delivery (before 37 weeks of gestation), which is a major cause of perinatal mortality and morbidity throughout the world (Beck et al. 2010). On the other hand, $\sim 4 \%$ of women deliver post-term (42 weeks of gestation or more), and this is associated with complications such as placental insufficiency, stillbirth or neonatal death; more than half of them require induction of labour (loL), with increased risk of difficult instrumental delivery or caesarean section (Smith 2001, Olesen et al. 2006).

Increased understanding of human parturition will help control the onset and management of labour and help reduce the incidence of preterm and post-term deliveries (Slattery \& Morrison 2002, lams et al. 2008). However, despite advances in clinical and laboratory research, the mechanism of human parturition is not well known (López Bernal 2003, Catalano et al. 2010). Excellent studies in pregnant sheep have demonstrated the involvement of the fetal pituitary-adrenal axis in the onset of labour (Liggins 1979) and the role of cortisol in the induction of placental enzymes regulating progesterone metabolism before delivery (Anderson et al. 1975). In rodents, parturition depends on activation of intrauterine prostaglandin release and the demise of the corpus luteum in the ovary. However, these animal mechanisms are not applicable to women because of differences in placental, uterine and ovarian function between primates and other mammals (Mitchell \& Taggart 2009). Evidence from studies in rhesus monkeys suggests that activation of the fetal pituitary-adrenal axis, as demonstrated by increased levels of DHEAS (which is a precursor for placental oestrogens in the placenta) in the fetal circulation, is associated with parturition (Mecenas et al. 1996, Giussani et al. 1998). While efforts to understand human parturition will continue to involve research using animal models, progress will benefit from direct studies in pregnant women. 
The onset of labour in women could be due to loss of uterine quiescence, the induction of uterine contractility or a combination of both (Price \& Lopez Bernal 2001, López Bernal 2003). Multiple related pathways have been studied: one of the pathways involves corticotrophin-releasing hormone (CRH; McLean et al. 1995). CRH levels in the maternal circulation increase exponentially from the second trimester with advancing gestation and reach a peak at delivery (Smith 2007). At a molecular level, CRH binds to specific receptors in myometrium and functions through the CAMP pathway to keep the uterus quiescent during pregnancy. At term, a change in $\mathrm{CRH}$ receptors in myometrium reduces CRH function (Smith 2007), and at the same time, increased oxytocin receptor activity, gap junctions and prostaglandin release promote labour (Grammatopoulos \& Hillhouse 1999, Maul et al. 2003). Inflammatory pathways have also been linked with changes in prostaglandin release and initiation of labour (López Bernal et al. 1989, Keelan et al. 1997, 2003). During pregnancy, progesterone maintains uterine quiescence by blocking myometrial contractions, and it is thought that labour is initiated by withdrawal of the progesterone blockade, which allows the muscle to enter the labouring state (Csapo 1956). However, while this may be true of some animal species (e.g. sheep, mice and rats), the role of progesterone withdrawal in human parturition remains controversial (Mitchell \& Taggart 2009). On the other hand, changes in the sensitivity to uterotonic agents such as oxytocin, prostaglandins or endothelin may trigger the onset of labour (López Bernal 2003, 2007). Other agents such as epidermal growth factor and uterine relaxants, such as $\beta_{2}$ adrenoceptor agonists and phosphodiesterase inhibitors, may be involved in maintaining uterine quiescence through transactivation of uterine receptors and modulating cyclic nucleotide pathways (Yuan \& Lopez Bernal 2007). Surfactant protein A (SP-A) levels increase exponentially towards term in human amniotic fluid (Miyamura et al. 1994), and a role for SP-A in regulating pro-inflammatory cytokine (IL1 $\beta$, TNF- $\alpha$ ) production by intrauterine tissues has been proposed, but its role in human parturition remains controversial (Lee et al. 2010). It is possible that different pathways interact with each other and that other as yet unknown factors are involved. The advent of reliable proteomics methodology has opened a new window of opportunity in the study of human parturition by allowing the simultaneous study of multiple proteins in complex biological samples (Pereira et al. 2007, Scholl et al. 2012). The need for clinically useful biomarkers to predict preterm labour remains (Conde-Agudelo et al. 2011).

In this paper, we have used proteomic techniques based on differential in-gel electrophoresis (DiGE) for a global analysis of changes in low abundance plasma proteins in relation to mode of onset of labour and delivery. This approach has disclosed novel pathways that widen our understanding of the process of spontaneous and induced labour in women.

\section{Results}

\section{DiGE analysis of intervillous plasma samples}

Normalized DiGE data sets of 21 unique placental intervillous plasma samples were used to study the proteomic patterns among the five labour/delivery groups. As shown in Fig. 1, an unsupervised k-mean cluster based on all protein spots grouped the samples into five categories. Most of the women delivered by emergency caesarean section clustered together, except one patient who had a caesarean due to failure to progress after spontaneous onset labour (ID: 57892). Three of four women from the spontaneous vaginal delivery (SVD) group had similar proteomic patterns except one sample (ID: 57776) whose pattern was more comparable to women having elective caesarean section (NiL). There was strong heterogeneity in the loL vaginal delivery group as one sample (ID: 57846) clustered with women having elective caesarean section (NiL) and another sample (ID: 57841) had no common pattern with any other groups. Heterogeneity was also revealed in the NiL group as one sample (ID: 57774) appeared similar with women having induction of labour and the other sample (ID: 57800) was classified as SVD.

Protein expression differences in intervillous plasma were estimated by unpaired comparison of all the in-labour cases (SVD, IoL, spontaneous labour followed by emergency caesarean section (SLEC) and induced labour followed by emergency caesarean section (ILEC)) with the NiL group. The number of protein spot changes for each group is presented in Table 1. A total of 92 protein spots were selected for analysis by mass spectrometry, and for 59 of them (64\%), we obtained confident identification. These proteins were the products of 33 genes, shown in Table 2. There were 25 protein spots from 14 unique genes with significant expression differences in SVD compared with NiL. In the loL group, 15 significantly different protein spots were identified representing 12 genes. In both emergency section groups, 17 differentially expressed protein spots were identified, corresponding to 11 genes in the SLEC group, and 10 genes in the ILEC group. The expressions of the protein isoforms from each gene were consistent in both change of direction and fold change.

The majority of the gene products identified which changed significantly in more than one mode of delivery compared with NiL showed a similar change. However, amyloid P component of serum (APCS) and apolipoprotein A-IV (APOA4) were found to be down-regulated in the SVD group (fold change for APCS was -1.5 and for APOA4 -1.6) but had increased expression in the ILEC 


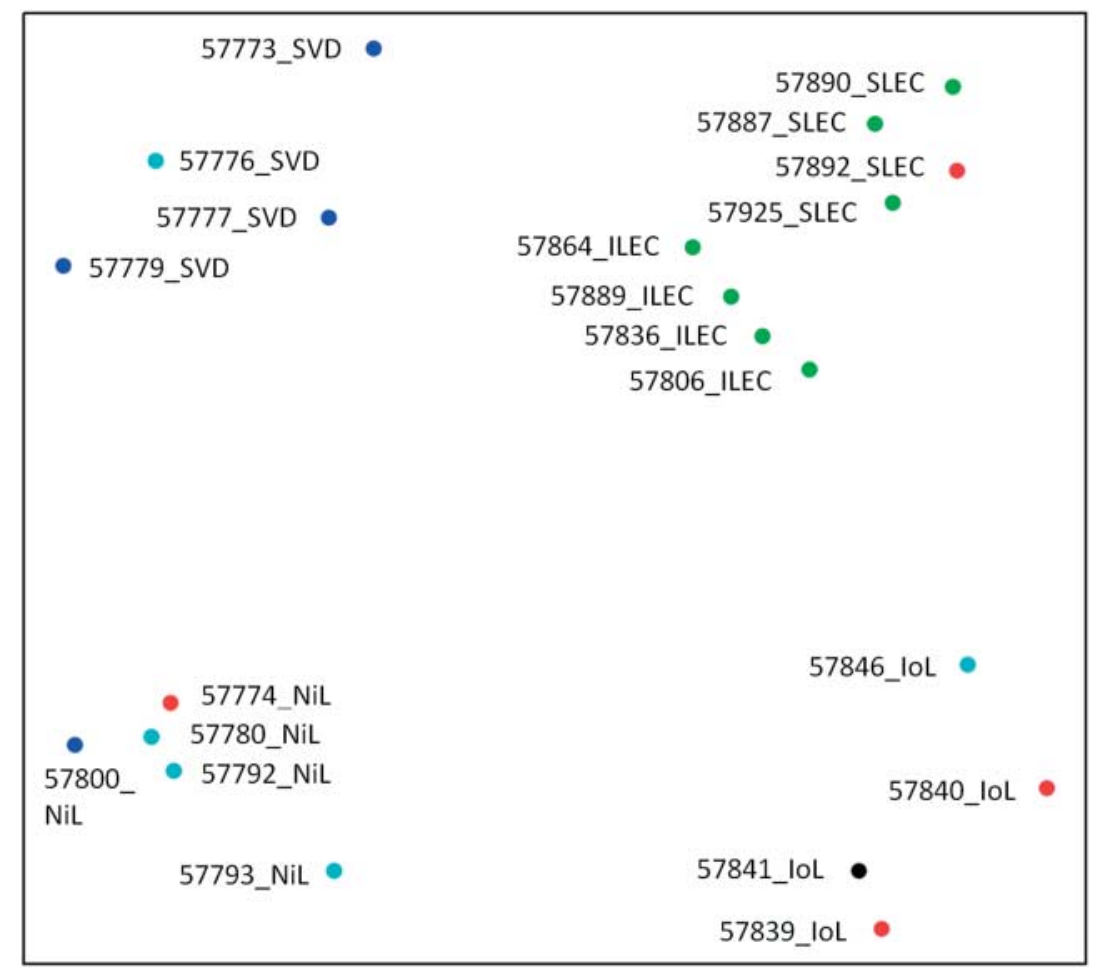

Figure 1 Unsupervised k-mean cluster of 21 unique placental intervillous plasma samples. The abbreviations describe the original group and the colour of the spots indicates the cluster each sample belongs to after k-mean analysis. The position of each spot is generated by cluster software based on its actual biological group, which is not expression related. The numbers refer to sample ID. group (APCS fold change 1.5) and IoL group (APOA4 fold change 1.4), respectively.

\section{DiGE analysis of pre- and in-labour maternal plasma samples}

In order to confirm the effect of labour on the maternal plasma proteome, a further DiGE analysis was carried out on serial blood samples obtained from six women before and after the onset of spontaneous labour (SVD group). In this analysis, 17 proteins were found to be down-regulated (median fold change 1.2, change range 1.1-1.4), while 33 proteins were up-regulated (median fold change 1.1, change range 1.1-1.6) by labour. The largest fold change was found with $\mathrm{C} 4 \mathrm{~B}$, which decreased 1.56-fold in spontaneous labour compared with the pre-labour status in the same women, while other proteins from inflammatory pathway genes (CFI and complement component $1, r$ subcomponent $(\mathrm{C} 1 \mathrm{R})$ ) also decreased (Table 3). A similar decreasing trend in the levels of inflammatory gene-related proteins was found in placental intervillous plasma.

\section{In silico analysis of parturition pathways: gene ontology}

Gene ontology of the 33 identified protein products was performed in order to find out the possible signalling pathways involved in the different modes of delivery. The majority of the proteins found to change significantly in the four labour/delivery-mode comparisons are from the extracellular region (GO: 0005576, GO: 0005615 and GO: 0044421), which is reassuring because it demonstrates low contamination from intracellular proteins. The molecular function analysis showed that the proteins that changed significantly in SVD are associated with oxygen binding and transport (GO: 0019825 and GO: 0005344), with defence responses (GO: 0006952) and with innate immunity (GO: 0045087). Proteins obtained by comparing SLEC to NiL have a role in fatty acid binding (GO: 0005504), and they are known to be involved in positive regulation of the immune response. Proteins found differentially expressed in the $\mathrm{IoL}$ group belong to enzyme inhibitors (GO: 0004857, GO: 0004867, GO: 0030234, GO: 0004866 and GO: 0030414) and signal transporters (GO: 0060228, GO: 0017127 and GO: 0015248). In contrast to SLEC, the gene products found to change in IoL are involved in negative regulation of the immune and defence responses.

The functions of the proteins that changed significantly in the ILEC group fall into four categories. One of the

Table 1 Differentially regulated protein spots (in relation to $\mathrm{NiL}$ ) identified in placental intervillous plasma by DiGE.

\begin{tabular}{lcccc}
\hline Group & $\begin{array}{c}\text { Number of } \\
\text { up-regulated } \\
\text { protein spots }\end{array}$ & $\begin{array}{c}\text { Median } \\
\text { (range) of } \\
\text { fold change }\end{array}$ & $\begin{array}{c}\text { Number of } \\
\text { down-regulated } \\
\text { protein spots }\end{array}$ & $\begin{array}{c}\text { Median } \\
\text { (range) of } \\
\text { fold change }\end{array}$ \\
SVD & 53 & $2.6(1.4-7.1)$ & 38 & $1.6(1.4-2.7)$ \\
loL & 49 & $1.9(1.3-3.4)$ & 28 & $1.7(1.4-2.8)$ \\
SLEC & 56 & $2.0(1.4-4.5)$ & 48 & $1.8(1.4-4.0)$ \\
ILEC & 63 & $2.0(1.4-3.8)$ & 39 & $1.7(1.3-7.3)$ \\
\hline
\end{tabular}


Table 2 Mean fold change of proteins identified by DiGE and MS in placental intervillous plasma in relation to mode of onset of labour and delivery. Negative values indicate higher expression in NiL, and positive values indicate lower expression in NiL.

\begin{tabular}{|c|c|c|c|c|}
\hline $\begin{array}{l}\text { Gene } \\
\text { symbol }\end{array}$ & ILEC - NiL & SLEC - NiL & SVD - NiL & IoL - NiL \\
\hline$A Z G P 1$ & -1.6 & -1.7 & -1.6 & - \\
\hline$A 2 M$ & 1.9 & 1.9 & - & 1.8 \\
\hline$C 1 R$ & - & -1.5 & -1.7 & -1.4 \\
\hline$A L B$ & -2.2 & -2.2 & - & - \\
\hline$A P O E$ & -1.4 & - & - & -1.4 \\
\hline$A P C S$ & 1.5 & - & -1.5 & - \\
\hline ITIH4 & 1.5 & 1.5 & - & - \\
\hline$H P X$ & - & -1.4 & -1.6 & - \\
\hline APOA4 & _- & - & -1.6 & 1.4 \\
\hline SERPINF1 & - & - & -1.5 & -1.5 \\
\hline $\mathrm{CFH}$ & - & _- & 1.4 & 1.6 \\
\hline TPI1 & -1.8 & - & - & - \\
\hline $\mathrm{ZC} 3 \mathrm{H}_{13}$ & -1.6 & - & - & _- \\
\hline CFI & -1.4 & - & - & - \\
\hline АРОC 3 & 2.2 & - & - & - \\
\hline C8G & - & -1.9 & _- & _- \\
\hline CFD & - & -1.7 & - & - \\
\hline LRG1 & - & -1.6 & - & - \\
\hline F2 & - & 1.4 & - & _- \\
\hline$C 7$ & - & 1.5 & - & - \\
\hline AFP & _- & - & -2.1 & _- \\
\hline$G S N$ & - & - & -1.6 & - \\
\hline ITIH1 & - & - & 1.6 & - \\
\hline CST3 & _- & _- & 1.9 & - \\
\hline$H B B$ & - & - & 4.3 & - \\
\hline$H B G 2$ & - & - & 4.6 & - \\
\hline HBA1 & - & - & 4.7 & - \\
\hline$A 1 B G$ & - & - & - & 1.6 \\
\hline AHSG & _- & _- & _- & 1.3 \\
\hline$A M B P$ & - & - & - & -1.7 \\
\hline$A N X A 1$ & _- & _- & - & -2.1 \\
\hline IGHG1 & - & - & - & 2.3 \\
\hline ITIH3 & - & - & - & 1.5 \\
\hline
\end{tabular}

categories corresponds to the pathway found in SLEC, that is fatty acid binding (GO: 0005504). Another function is represented in $\mathrm{loL}$ as enzyme inhibitor (GO: 004857). The other two functions are unique to the ILEC group: lipoprotein receptor (GO: 0070325) and antioxidant (GO: 0016209). As regards the various molecular functions of ILEC proteins, the biological processes involved show a wide range including inflammatory response, negative regulation of defence response, signal transduction and lipid metabolism.

In summary, immune and defence response are the major pathways found differentially expressed in labour, although changes in signal transduction and regulation were also found among the four modes of delivery. However, some of the pathways found in the different modes of delivery may reflect differences in the management of the labour process in these groups. For example, changes in oxygen transporters have been found in only SVD, while several small molecule transporters have been found in induction-related deliveries (IOL and ILEC).

In the maternal circulation, 14 out of the 50 gene products that changed with labour come from the innate immune response pathway (GO: 0045087).
In comparison with placental plasma, more genes involved in cholesterol transport (GO: 0030301) and blood coagulation pathway (GO: 0007596) were found to be changed during labour.

\section{In silico analysis of labour pathways: Ingenuity Pathway Analysis database}

The Ingenuity Pathway Analysis (IPA) database contains the extended database of gene ontology, and the results we obtained from IPA analysis reflected the results from

Table 3 Mean fold change of proteins identified by DiGE and MS in maternal plasma from spontaneous vaginal deliveries. Negative values indicate higher expression in-labour, and positive values indicate lower expression in-labour.

\begin{tabular}{|c|c|}
\hline Gene symbol & Pre- to in-spontaneous labour \\
\hline$A L B$ & -1.33 \\
\hline$A M B P$ & -1.29 \\
\hline$A Z G P 1$ & -1.15 \\
\hline ATRN & -1.1 \\
\hline CNTRL & -1.1 \\
\hline CLU & -1.37 \\
\hline$F 2$ & -1.07 \\
\hline$C 1 R$ & -1.09 \\
\hline$C 4 B$ & -1.56 \\
\hline CFI & -1.1 \\
\hline ERC1 & -1.1 \\
\hline FETUB & -1.07 \\
\hline FHAD1 & -1.1 \\
\hline$G S N$ & -1.12 \\
\hline GPLD1 & -1.16 \\
\hline$G C$ & -1.11 \\
\hline$H P X$ & -1.07 \\
\hline$D D \times 39 B$ & -1.23 \\
\hline ITIH1 & -1.06 \\
\hline ITIH4 & -1.18 \\
\hline KIAA1328 & -1.1 \\
\hline KIF4A & -1.1 \\
\hline KNG1 & -1.1 \\
\hline LRG1 & -1.15 \\
\hline PON1 & -1.35 \\
\hline PRDX2 & -1.63 \\
\hline PLEC & -1.14 \\
\hline PSG1 & -1.11 \\
\hline PSG11 & -1.15 \\
\hline PSG7 & -1.11 \\
\hline PIBF1 & -1.14 \\
\hline PPFIA4 & -1.1 \\
\hline$S M C 1 A$ & -1.1 \\
\hline ACTB & 1.44 \\
\hline$A 2 M$ & 1.15 \\
\hline APOA4 & 1.18 \\
\hline APOC2 & 1.32 \\
\hline APOC 3 & 1.22 \\
\hline $\mathrm{APOH}$ & 1.19 \\
\hline C1S & 1.15 \\
\hline C6 & 1.05 \\
\hline$C 8 A$ & 1.07 \\
\hline$C F B$ & 1.14 \\
\hline $\mathrm{CFH}$ & 1.05 \\
\hline ERC1 & 1.37 \\
\hline$F G B$ & 1.34 \\
\hline FCN3 & 1.29 \\
\hline POTEE & 1.44 \\
\hline RAl14 & 1.07 \\
\hline TBK1 & 1.07 \\
\hline
\end{tabular}


GoMiner but with detailed pathway networks. As with GoMiner, IPA located the majority of proteins in the extracellular space $(n=26)$. The rest of the proteins were cytoplasmic (HBA1, HBB, HBG2, TPI1 and C7), plasma membrane proteins (annexin A1 (ANXA1)) or unknown $(\mathrm{ZC} 3 \mathrm{H} 13)$. In order to minimize the potential effect from the cytoplasmic pathways, the network analysis was focused on the 26 extracellular proteins plus ANXA1 (situated on the plasma membrane). The core network pathways involved in labour were metabolic and inflammatory. As shown in Fig. 2, the results indicate that different modes of delivery use different signal processes to regulate the core pathways. Fewer signal transduction steps were detected in SVD compared with the other three modes of delivery. In addition, the protein network involved in the ILEC group overlapped with networks in the SLEC and loL groups. However, only two proteins appeared in both IoL and SLEC networks (hepatocyte nuclear factor 1 homeobox A (HNF1A) and A2M, Fig. 2). Remarkably, only HNF1A appeared in all four modes of delivery.

IPA analysis was also performed to identify pathway alterations in spontaneous labour using serial maternal plasma samples. Inflammatory response pathways centred in TNF and IL8 were identified (Supplementary Figure 1, see section on supplementary data given at the end of this article). Moreover, as with placental plasma, the HNF1A-related pathway was involved (Supplementary Figure 2, see section on supplementary data given at the end of this article; Yuan 2011).

\section{Protein biomarker validation}

In the DiGE experiment, APOA4, APOE and APOC3 were associated with the onset of labour.
Apolipoproteins can also work as enzyme cofactors to influence signal transduction. Therefore, it is possible that apolipoproteins both promote the onset of labour and have the potential to be biomarkers for labour. APOA4 and APOE were selected for further validation based on the availability of reliable commercial antibodies.

\section{Apolipoprotein A-IV}

The presence of APOA4 in placental intervillous plasma was confirmed using western blotting in nine samples each of SVD and NiL, matched as closely as possible for maternal age and gestational age at birth (Fig. 3). The result of the immunoblots agreed with those of the DiGE experiment (Table 2) in that the level of APOA4 was lower in SVD compared with NiL; the difference in the APOA4/IgG ratios for these groups was statistically significant $(P=0.0078)$.

Further validation of APOA4 was carried out in serial samples of maternal peripheral plasma taken before and during labour/at caesarean section, in women from the SVD $(n=6)$, IoL $(n=6)$ and NiL $(n=6)$ groups (Fig. 4$)$. In the SVD group, the protein change confirmed the trend found in the DiGE experiment; however, it did not reach statistical significance probably due to small sample number.

\section{APOE}

The level of APOE in placental intervillous plasma was measured by western blotting in nine samples each of SVD and NiL, as for APOA4 (Fig. 3). There was no significant difference in this comparison, which agrees with the DiGE results. APOE levels were also measured

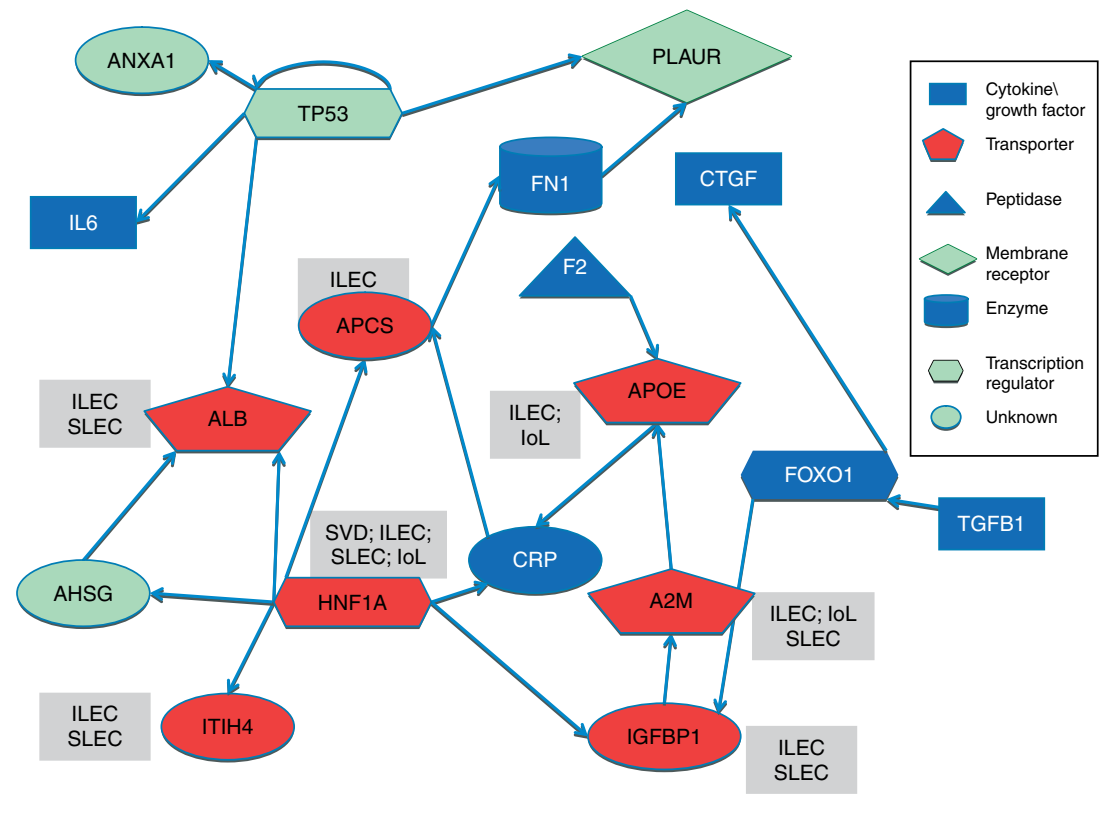

Figure 2 Network analysis of the proteins found in the DiGE experiments using IPA. Red colour indicates protein changes in more than one group (given in the grey rectangles). Light green colour means protein changes in IoL only, blue colour means protein changes in SLEC only. The box explains the functional allocation of the proteins Note the central role of HNF1A. 

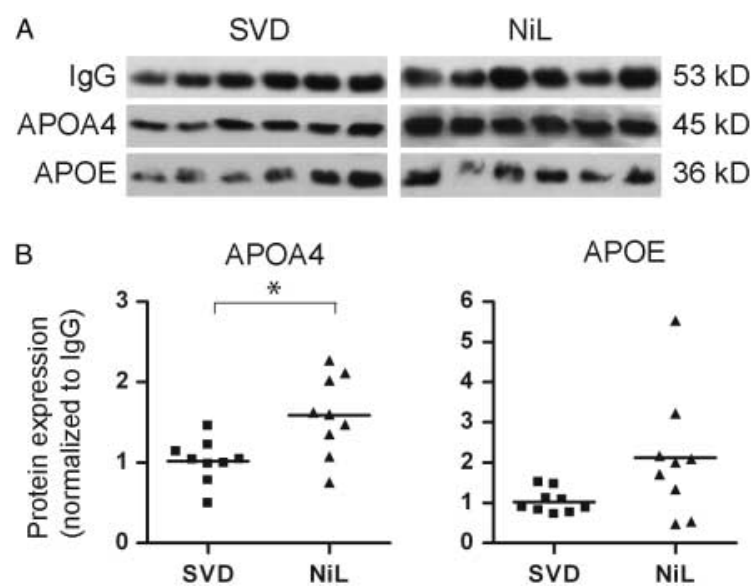

Figure 3 Levels of APOA4 and APOE proteins in placental intervillous plasma. Plasma was collected following spontaneous vaginal delivery (SVD) or elective caesarean section (NiL) and analysed by western blotting, as described in Materials and Methods section. (A) Representative blots of IgG, APOA4 and APOE in SVD and NiL plasma $(n=6)$. (B) APOA4 and APOE levels, normalized to levels of IgG (individual and mean levels shown). $n=9$ in each group. For APOA4, there was a significant difference between the means of the SVD and NiL groups $(* P<0.01)$.

in serial samples of maternal peripheral plasma, as for APOA4 (Fig. 4). There were no differences in APOE/lgG levels between the pre- and in-labour groups in SVD, NiL or loL women. Likewise, with DiGE, no significant difference was seen between SVD pre- and in-labour levels of APOE (Table 3). No differences between the SVD, NiL and IoL groups were identified by ANOVA analysis of the western blotting results.

\section{RIAs}

In order to obtain more information about lipoprotein changes with labour, APOE, lipoprotein A (LPOA), APOA 1 and APOB estimations were carried out in serial maternal plasma samples by established RIAs. This allowed the determination of absolute levels of these proteins in the different groups. As seen in DiGE, the level of APOE was higher in NiL (mean \pm s.D. $=92.3$ $\pm 23.0 \mathrm{mg} / \mathrm{l})$ than in $\mathrm{IoL}(63.7 \pm 23.9 \mathrm{mg} / \mathrm{l}) ; n=10$, $\bar{P}=0.08)$ or in SVD $(64.8 \pm 13.9 \mathrm{mg} / \mathrm{l} ; n=10, P=0.02)$. In contrast to APOE, the levels of LOPA, APOA1 and APOB did not change at the time of delivery.

\section{Discussion}

\section{HNF1A is a key mediator of human parturition}

Parturition involves complex interactions across multiple signalling pathways that converge in functional uterine changes, notably cervical ripening and dilatation and myometrial contractions. In the DiGE-MS approach, we have identified 59 proteins from 33 genes involved in human parturition. Some of the proteins have a consistent expression pattern across different modes of delivery. For example, the decrease of C1R in SVD, SLEC and loL suggests the existence of a common pathway in the process of labour. However, there was no single protein that changed in all modes of delivery. The analysis using IPA indicates that genes that regulate HNF1A and genes that are regulated by HNF1A are involved in all modes of labour and delivery, which suggests that HNF1A may be a part of the common human parturition signal network. Here, we name it the HNF1A pathway (Fig. 2, red colour molecules).

In this signalling pathway, HNF1A acts as a key protein that regulates several other proteins directly, including albumin (ALB) and APCS. HNF1A is a transcription factor expressed in human placenta, liver, kidney, pancreatic islets and intestine but has not been described in myometrium (Mendel et al. 1991, GautierStein et al. 2006). Physiological studies of HNF1A have found that it controls insulin-signalling transduction and that it is essential in linking metabolic and inflammatory pathways (Eeckhoute et al. 2004). HNF1A is among several factors implicated in the pathogenesis of gestational diabetes (Shaat \& Groop 2007). The range of proteins regulated by HNF1A is very broad, including acute phase proteins such as ALB, alpha fetoprotein (AFP), CRP, fibrinogen, insulin-like growth factor and APCS; proteins involved in cholesterol/lipoprotein metabolism such as APOB, APOA2, APOA1, APOC3,
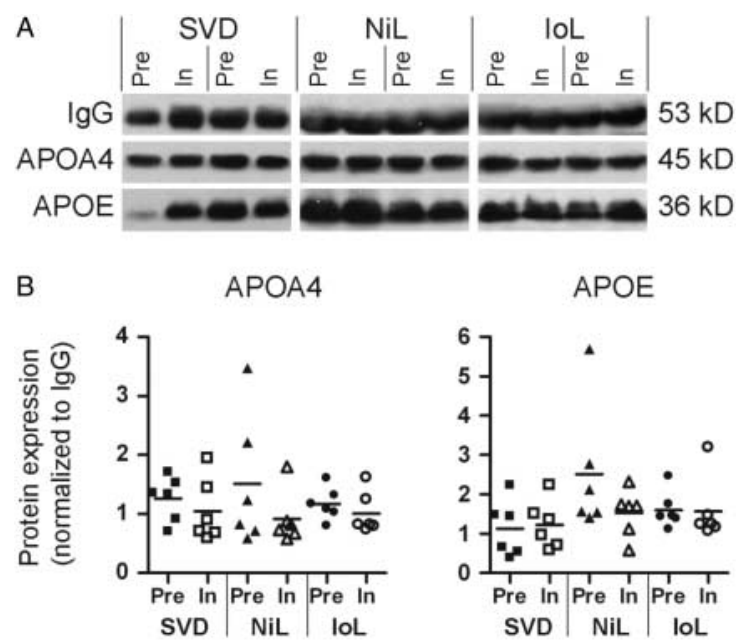

Figure 4 Levels of APOA4 and APOE proteins in maternal peripheral plasma. Plasma was collected from women undergoing spontaneous vaginal delivery (SVD), elective caesarean section (NiL) or induction of labour (loL), with paired pre- and in-labour samples taken from each subject (for the NiL group, in-labour samples were taken at the time of caesarean section). Samples were analysed by western blotting, as described in Materials and Methods section. (A) Representative blots of IgG, APOA4 and APOE in SVD, NiL and loL plasma ( $n=2$ pairs). (B) APOA4 and APOE levels, normalized to levels of IgG (individual and mean levels shown). $n=6$ pairs in each group. No significant differences were observed between normalized protein expression levels in pre- and in-labour groups. 
APOM, lipoprotein lipase and acyl-coenzyme cholesterol acyltransferase 2; as well as proteins in glucose/fatty acid metabolism such as glucokinase, glucokinase regulator glucose transporter and liver fatty acid-binding protein (Armendariz \& Krauss 2009); and others such as interalpha globulin inhibitor $\mathrm{H} 4$ (ITIH4) and insulin-like growth factor binding protein 1 (IGFBP1). HNF1A may also be involved in metabolic programming of the fetus (Rodriguez-Trejo et al. 2012). An interesting finding from this study is the change with parturition in various proteins involved in triglyceride transport and metabolism. It is known that maternal triglyceride levels gradually rise in the first trimester of normal pregnancy and reach a peak during the second trimester (Choi \& Pai 2000, McGladdery \& Frohlich 2001). After delivery, triglyceride levels decrease rapidly, and the fall is faster in breastfeeding women compared with women without lactation (Qureshi et al. 1999). In placental intervillous plasma, the triglycerides transporter APOA4 was found to decrease in SVD and to increase in loL; APOE decreased in both IoL and ILEC and APOC3 increased in ILEC. This does not necessary mean that changes happened on the ability to transport triglycerides, because one apolipoprotein can be replaced by another, for example APOA4, which binds chylomicrons, can be displaced by APOC3 (Green et al. 1979, Hayashi et al. 1990). Our findings suggest a complex balance among triglyceride transporters and chylomicron metabolism during human parturition, and this balance could be adjusted according to delivery mode and/or onset of labour.

\section{Spontaneous labour and vaginal delivery}

We propose that the HNF1A pathway is central to human parturition; however, there may be characteristic changes in this and associated pathways for each mode of labour and delivery. For example, in the SVD group, AFP in placental and maternal peripheral blood decreased after delivery; this may be a consequence of down-regulation by retinoids mediated by HNF1A (Magee et al. 1998). This suggests that in SVD, there is a distinct mechanism within the HNF1A pathway to decrease AFP levels.

APCS, a glycoprotein, is another important link to the HNF1A pathway. APCS is produced in blood vessel walls and it can bind to fibronectin (FN1) to regulate human inflammatory pathways (de Beer et al. 1981) by depositing APCS-FN1 into blood plasma in response to inflammatory/immune stimuli (Breathnach et al. 1983). Although there is no direct evidence connecting APCS with the onset of labour, abnormal FN1 levels in the maternal circulation have long been associated with high risk of preterm birth (Pepys \& Baltz 1983). APCS is involved in modulating immune responses by promoting macrophage differentiation (Zhang et al. 2011), and there is strong interest in the role of decidual macrophages in pregnancy maintenance (Houser et al. 2011). APCS levels in maternal plasma decrease with delivery in SVD and increase in ILEC, which indicates that different modes of delivery may promote different inflammatory responses. Interestingly, HNF1A is involved in a new mechanism of inflammationinduced transcriptional repression by competing with pro-inflammatory JUN proteins on the same regulatory regions of human apolipoprotein promoters (Mosialou et al. 2011). The anti-inflammatory effect of HNF1A may be beneficial in promoting uterine quiescence.

Apart from the HNF1A pathway, this study has shown that there are other signalling networks involved in SVD. These include several proteins from inflammatory pathways: HPX, complement factor $\mathrm{H}(\mathrm{CFH}), \mathrm{C} 1 \mathrm{R}$, cystatin 3 (CST3), APOA4 and AZGP1. In contrast to HNF1A, CFH and C1R do not respond to high levels of IL6 but react to other cytokines such as interferongamma (Goldberg et al. 2007). This suggests that part of the SVD signals may be independent from and/or complementary to the HNF1A network. Furthermore, high levels of CFH in SVD could cause the inhibition of both the classical and alternative pathways of complement activation, which emphasizes that a balance in inflammatory pathways must be maintained during human parturition (Whaley \& Ruddy 1976, DiScipio 1981, 1992, Goldberg et al. 2007). Several proteins associated with TNF were found to change in maternal peripheral plasma with labour. A possible involvement of TNF in the mechanism of human term and preterm parturition has been proposed (Casey et al. 1989). TNF stimulates prostaglandin production by the amnion, decidua and myometrium (Hertelendy et al. 1993), and recent reports suggest that the uterus becomes very sensitive to TNF with advancing gestation and labour (Alexander et al. 2012).

In the SVD group, APOA4 decreased in both placental and maternal plasma with delivery. Few studies of APOA4 levels in human pregnancy or parturition have been carried out, but it is known that APOA4 activates the enzyme lecithin:cholesterol acyl transferase and modulates lipoprotein lipase activity. Moreover, APOA4 mediates the metabolism of chylomicrons and may be important in regulating plasma lipid levels. Collectively, these actions could promote the transport of cholesterol from extra-hepatic tissue and cells to the liver (Wong et al. 2007). In addition, APOA4 possesses antiatherogenic (Warner et al. 2001) as well as anti-oxidant properties (Wong et al. 2007). In mice, a reduction of APOA4 levels exacerbated inflammatory responses (Vowinkel et al. 2004) and it is tempting to speculate that a decrease in maternal APOA4 levels may favour an inflammatory pathway in labour.

Beside the proteins involved in inflammatory pathways, there were several other proteins that changed in SVD in comparison to the NiL group. These included CST3, an endopeptidase inhibitor, which increased 
exclusively in the SVD group. CST3 is produced by virtually all nucleated cells at a constant production rate, unaltered in inflammatory conditions but closely correlated to kidney function in pregnant and non-pregnant women. High levels of CST3 during pregnancy are associated with a high risk of developing pre-eclampsia (Kristensen et al. 2007). CST3 participates in matrix metalloproteinase regulation in vaginal tissues during the peripartum period (Wieslander et al. 2008). Interestingly, in SVD, another two endopeptidase inhibitors, ITIH1 and serpin peptidase inhibitor F1 (SERPINF1), were also found increased and decreased respectively. These protein inhibitors might be involved in remodelling of placental tissues, and a low level of SERPINF1 in placenta has been reported to be significantly associated with increased risk of stillbirth (Plunkett et al. 2008). SERPINF1 may participate in the process of cervical ripening through its collagen binding and proteoglycan interactions (Sekiya et al. 2011). In addition, a study in pregnant rats has demonstrated that endopeptidase inhibitors enhance myometrial contractility compared with non-pregnant rats, which were not affected by endopeptidase inhibitors (Shintani et al. 2000).

Another key finding in the SVD group is the exclusive presence of proteins belonging to the haemoglobin family, such as HBA1, HBG2 and HBB. This gene family is known to be related to oxygen transport. During pregnancy and parturition, oxygen levels and its transport have to be constantly adjusted. At the time of implantation and early pregnancy, the oxygen level in the uterus is low (Jauniaux et al. 2000). This early pregnancy hypoxic environment is optimal for embryo development, because it keeps a low level of metabolism and thereby minimizes the production of reactive oxygen species, as well as providing a beneficial effect on early placental development (Charnock-Jones 2002). By the end of the first trimester, following the developments in the feto-placental interface, the placenta is exposed to higher oxygen levels and faces major oxidative challenges. Oxygen tension in the placenta continues to rise during the second trimester, in order to support the rapid fetal growth (Carter 2000) and then it decreases until term (Soothill et al. 1986). The increased expression of key antioxidant enzymes and improvement of their activities helps the placenta adapt its defences to suit the hyperoxic conditions (Jauniaux et al. 2000).

During normal term labour, the placenta's maternal arterial supply is cut off during uterine contractions, which can result in ischaemia-reperfusion stress (Grace \& Mathie 1999). This condition, similar to the cause of pre-eclampsia, would increase the haemoglobin expression level in placenta, which would be detectable in placental intervillous plasma. This could be the explanation for the increased expression of haemoglobin family proteins that we have found in the SVD group.

\section{Emergency caesarean section}

Our study has revealed that the SLEC and ILEC groups share very similar protein expression patterns and stand out from the non-emergency groups. This would suggest that emergency caesarean section is associated with a distinct pathway, which is different from the normal human parturition network.

Proteins found significantly and consistently changed in both SLEC and ILEC could represent a conserved emergency pathway. For instance, ITIH4, was increased 1.5 -fold in both SLEC and ILEC. This is an acute phase protein that can be regulated by HNF1A and has been functionally involved in cervical ripening and parturition in mice (Ruscheinsky et al. 2008) and in recurrent pregnancy loss in women (Kim et al. 2011). IGFBP1 was also increased in both emergency caesarean section groups, and its expression is regulated by cytokines (IL1 $\beta$ ) and hCG through HNF1A (Tang \& Gurpide 1993). Epidemiological studies have shown that elevated maternal serum IGFBP1 levels in the second and early third trimesters significantly associate with preeclampsia, intrauterine fetal growth restriction and other pregnancy complications (Bujold et al. 2008). At term, IGFBP1 levels are higher in spontaneous labour than in elective caesarean section; this may reflect the higher incidence of fetal hypoxia and/or fetal distress in active labour (Hills et al. 1996) and is supported by the results of elevated IGFBP1 in both ILEC and SLEC, as a possible consequence of fetal distress (Marchini et al. 2005). The decidua secretes phosphorylated isoforms of IGFBP1, which have been measured in cervical secretions as a predictor of preterm delivery with some success (Kekki et al. 2001).

Apart from the similarities, the differences in protein patterns between SLEC and ILEC may underlie the clinical indications for emergency caesarean sections. For example, various complement factors $(\mathrm{C} 1 \mathrm{R}, \mathrm{C} 7$, C8G and CFD) were found altered in SLEC but not in ILEC. The decrease in C1R, C8G and CFD, and the increase in $\mathrm{C7}$, may represent a balancing of inflammatory responses.

An interesting protein found to change in the SLEC group is CRP, which is also regulated by HNF1A. CRP is a sensitive biomarker of systemic inflammation and is primarily synthesized in hepatocytes in response to infection and tissue injury (Pepys \& Baltz 1983). Previous studies have shown that elevated levels of CRP in amniotic fluid and maternal plasma in the second trimester are strongly associated with spontaneous preterm birth (Wei et al. 2010). CRP levels in maternal blood of women at the onset of labour were significantly higher than in women who were not in labour (Törnblom et al. 2005); this agrees with the results of our DiGE analysis.

In the ILEC group, APOC3 and APOE were found to increase and decrease respectively. APOE is essential for 
the normal catabolism of triglyceride-rich lipoproteins and is involved in corpus luteum function and metabolic adaptations in the peripartum period in lactating animals (Ndikum-Moffor et al. 1997). Besides the well-known function of removal of excess cholesterol from the circulation via regulation of hepatic uptake (Belo et al. 2004), its function also involves modification of inflammatory responses, including suppressing $\mathrm{T}$ cell proliferation, macrophage regulation, lipid antigen presentation facilitation (by CD1) to natural killer $T$ cells, as well as modulation of inflammation and oxidation (Zhang et al. 2010). Epidemiological studies have reported that increased levels of APOE are associated with an increased risk of pre-eclampsia, whereas genetic association studies suggested that polymorphisms in $A P O E$ are also associated with preeclampsia (Atkinson et al. 2009) and spontaneous abortions in patients with endometriosis (Collazo et al. 2012). In addition, APOE is involved in inflammatory pathways. APOC3 is another apolipoprotein found in many triglyceride-rich lipoproteins (Zheng et al. 2010). The increase of APOC3 and decrease of APOE in the ILEC group suggests that hypertriglyceridaemia happens during the emergency section procedure following the loL.

\section{IoL and vaginal delivery}

Involvement of the HNF1A pathway (Fig. 2) in the IoL group was characterized by the appearance of several inflammation-related proteins, such as alpha2HS-glycoprotein (AHSG), one of the HNF1A target genes, as well as the complement proteins $\mathrm{C} 1 \mathrm{R}$ and CFH (Odom et al. 2004). Moreover, both A2M and APOE were found to change in loL, which supports the hypothesis that the formation of the A2M-APOE complex in human parturition is a downstream target of HNF1A (Hussain et al. 1991). There is no previous information on potential roles for AHSG in human parturition; however, maternal AHSG levels are low in pre-eclampsia (Molvarec et al. 2009) and a decrease in sialic acid content of AHSG has been described in plasma from neonates with intrauterine growth restriction (Karamessinis et al. 2008).

Interestingly, APOA4 decreased in SVD but increased in loL, which suggests that although women in both SVD and loL groups had successful vaginal deliveries, the different modes of onset of labour, spontaneous vs induced, required alternative pathways. This suggestion is further supported by the fact that several proteins changed uniquely in loL. For example, ANXA1 decreased exclusively in loL. ANXA1 is involved in the regulation of phospholipase $A_{2}$ activity and is a mediator of the anti-inflammatory actions of glucocorticoids. Administration of ANXA1 to mice results in anti-inflammatory effects by potent inhibition of neutrophil trafficking (Lim \& Pervaiz 2007). Therefore, the decrease of ANXA1 in the plasma of loL supports the idea that medical loL may provoke excess activation of inflammatory pathways. In addition, a decrease of ANXA1 expression can result in liberation of phospholipase A2 activity, making more arachidonic acid available for prostaglandin generation (Herbert et al. 2007), which is crucial in uterine contraction.

Moreover, alpha-1-B glycoprotein (A1BG) and immunoglobulin heavy constant gamma 1 (IGHG1) proteins increased whereas alpha-1-microglobulin precursor (AMBP) decreased exclusively in loL. AMBP is reported to be increased in the amniotic fluid of women delivering at term compared with preterm deliveries (Bujold et al. 2008). Further studies are required to understand the involvement of this group of proteins in pregnancy and parturition.

\section{Strengths and limitations}

The initiation of labour is a complex physiological process and different modes of delivery apparently result in specific modifications of the parturition pathway. These variations could be one of the reasons why it has been difficult to develop drugs to delay safely and effectively the onset of preterm labour. Preterm labour may have a multifactorial aetiology and there are complications such as premature rupture of the membranes or vaginal bleeding that may underlie pathological pathways different from those involved in labour at term. In this study, we have considered two modes of onset of labour, spontaneous and induced, as well as three modes of delivery, vaginal, elective caesarean section and emergency caesarean section. The overlap in proteomic changes of the different modes of labour onset and delivery suggests a common pathway for human parturition involving HNF1A. This finding has been reinforced by comparing serial pre- and in-labour maternal plasma samples and highlights the importance of the HNF1A pathway and the need to investigate the functional involvement of HNF1A-regulated proteins in uterine function. This approach may discover specific drug targets for clinical applications. However, this study cannot differentiate between changes that are related to the cause of labour and changes that are the result of activation of the labour mechanism. For instance, the potential effects of the procedures for the loL (intravaginal prostaglandins, artificial rupture of the membranes and intravenous oxytocin) alone or in combinations on the levels of plasma proteins are not known and may have contributed to heterogeneity in the loL groups. The reasons for emergency caesarean section included failure to progress, fetal distress and failed induction. The different physiopathological mechanisms underlying these situations, e.g. protracted uterine activity vs acute fetal hypoxia and stress responses, may have provoked distinct alterations in plasma proteins levels. Finally, heterogeneity in the elective caesarean section group 
may have arisen because at the time of the section some women may have been much closer to the spontaneous onset of labour than others. In theory, some of this heterogeneity could be determined by obtaining a Bishop Score, but this is a subjective and poorly reproducible score and vaginal examination is not routinely performed before elective caesarean section.

Given that the number of samples that can be analysed by DiGE is relatively small, differences in the clinical presentation of women or in the management of labour and delivery may have influenced the results. Moreover, the protein changes detected could be relatively small due to dilution in a large volume of plasma and the influence of many organs in the composition of the maternal plasma proteome. Changes at the fetomaternal interface may be greater but would be more difficult to sample in a non-invasive manner. Future studies will be facilitated by more efficient and rapid proteomic techniques that allow the processing of larger sample numbers. This would allow better control of clinical heterogeneity. The answers to these challenges need further studies with methods that allow frequent serial estimations of maternal plasma proteins in women before and after labour, combined with in vitro and ex vivo physiological experiments using fresh intrauterine tissues.

\section{Materials and Methods}

\section{Clinical groups}

We obtained placental intervillous blood from five groups of women according to their onset of labour and mode of delivery: elective caesarean section (not in labour, NiL), SVD, IoL, SLEC and ILEC (Table 4). We also obtained venous blood from women who were delivered within 2 days of recruitment and who went into spontaneous labour and had a vaginal delivery (serial-SVD), from women whose labour was induced and had a vaginal delivery (serial-loL) and from women who were delivered by elective caesarean section with no signs of labour (serial-NiL). We obtained two blood samples from each woman. The first serial blood sample was taken at the time of the initial assessment, when there were no signs of labour and the second sample at the time of established labour or elective caesarean section. Thus, we were able to compare peripheral blood from the same women before and after the onset of labour and from women who did not go into labour within the same time interval. Each patient was given an anonymized ID number. Clinical details are given in Table 4. Labour was induced with intravaginal prostaglandins, artificial rupture of the membranes and/or intravenous oxytocin. The length of labour in women with spontaneous onset was $5 \mathrm{~h}$ (1 h 40 min$21 \mathrm{~h} 45 \mathrm{~min}$ ) (median and range) and in women with induced labour $8 \mathrm{~h} 30 \mathrm{~min}(8 \mathrm{~h} 30 \mathrm{~min}-21 \mathrm{~h} 30 \mathrm{~min})$. Thus, the length of labour in spontaneous and induction groups was similar; however, there was a wide range of values in both groups, which may have given rise to heterogeneity in plasma protein levels. The reasons for emergency caesarean section included failure to progress, malposition, fetal distress, breech presentation and failed induction. All women had active management of the third stage of labour with an oxytocin agent (either oxytocin $5 \mathrm{IU}$ alone or combined with ergometrine $250 \mu \mathrm{g}$ administered intramuscularly or intravenously). In most cases including caesarean sections, delivery of the placenta was by controlled cord traction. All women delivered in St Michael's Hospital, Bristol, UK, and were of British White origin with good general health and had singleton pregnancies without complications such as infection, antepartum haemorrhage, hypertension, pre-eclampsia, diabetes or intrauterine growth restriction. The study was approved by the Central and South Bristol Research Ethics Committee and all women gave informed written consent.

\section{Placental intervillous plasma}

Human placental intervillous plasma was collected as soon as possible after delivery. The maternal side of the placenta was cut open, and $4 \mathrm{ml}$ whole blood was collected by syringe from the placental intervillous space. Blood was transferred immediately into a pre-prepared $\mathrm{K}_{2}$ EDTA collection tube containing leupeptin hydrochloride $(1 \mu \mathrm{g} / \mathrm{ml})$, aprotinin $(1 \mu \mathrm{g} / \mathrm{ml})$ and pepstatin $\mathrm{A}(1 \mu \mathrm{g} / \mathrm{ml})$ and mixed well. Plasma was separated by centrifugation at $2000 \mathrm{~g}$ for $10 \mathrm{~min}$ at room temperature. Clear plasma was given a further spin at $12000 \mathrm{~g}$ for $5 \mathrm{~min}$. Supernatant was taken and divided into $6-8$ aliquots, then frozen in liquid nitrogen and stored at $-80^{\circ} \mathrm{C}$.

Table 4 Clinical details of women according to onset of labour and mode of delivery.

\begin{tabular}{|c|c|c|c|c|c|}
\hline & $\begin{array}{l}\text { Number } \\
\text { of women }\end{array}$ & $\begin{array}{l}\text { Median maternal age } \\
\text { (range; years) }\end{array}$ & $\begin{array}{l}\text { Median gestational age } \\
\text { (range; weeks) }\end{array}$ & $\begin{array}{l}\text { Median newborn } \\
\text { weight (range; } \mathrm{kg} \text { ) }\end{array}$ & $\begin{array}{c}\text { Fetal sex } \\
\text { male/female }\end{array}$ \\
\hline \multicolumn{6}{|l|}{ Placental intervillous blood } \\
\hline Elective caesarean section (NiL) & 5 & $35(34-39)$ & $39(39-40)$ & $3.5(3.2-3.9)$ & $3 / 2$ \\
\hline Spontaneous vaginal delivery (SVD) & 4 & $29(19-36)$ & $41(39-41)$ & $3.4(3.2-4.0)$ & $3 / 1$ \\
\hline Induction of labour vaginal delivery (loL) & 4 & $31(27-42)$ & $42(40-42)$ & $3.7(3.4-4.5)$ & $3 / 1$ \\
\hline $\begin{array}{l}\text { Spontaneous labour, emergency } \\
\text { caesarean section (SLEC) }\end{array}$ & 4 & $27(21-35)$ & $41(37-41)$ & $3.7(3.4-3.9)$ & $3 / 1$ \\
\hline $\begin{array}{l}\text { Induction of labour, emergency caesarean } \\
\text { section (ILEC) }\end{array}$ & 4 & $28(25-44)$ & $40(38-41)$ & $3.5(3.4-4.2)$ & $3 / 1$ \\
\hline \multicolumn{6}{|l|}{ Maternal peripheral blood } \\
\hline Serial-SV́D & 10 & $36(21-46)$ & $41(39-42)$ & $3.9(3.1-4.3)$ & $5 / 5$ \\
\hline Serial-IoL & 5 & $29(19-34)$ & $42(41-42)$ & $4.0(2.9-4.4)$ & $3 / 2$ \\
\hline Serial-NiL & 5 & $35(28-46)$ & $40(38-42)$ & $3.6(3.0-4.1)$ & $3 / 2$ \\
\hline
\end{tabular}




\section{Maternal plasma}

Maternal peripheral blood samples were collected from women before delivery and from the same women at the onset of labour or just before delivery by caesarean section. The blood samples were treated and the plasma stored in the same way as described earlier for placental intervillous blood.

\section{Differential in-gel electrophoresis}

Two DiGE experiments were carried out: in the first experiment, we compared placental intervillous blood from five groups of women, NiL, SVD, IoL, SLEC and ILEC (Tables 1 and 2); the second used peripheral vein blood from women recruited in the serial-SVD group (Table 3). Placental intervillous plasma samples from 21 women were used for DiGE. In all samples, the 20 most abundant proteins (including $A L B$, IgG and transferrin) were removed from the plasma using the ProteoPrep20 immunodepletion kit form Sigma. The immunodepleted samples were then resuspended in $7 \mathrm{M}$ urea, $2 \mathrm{M}$ thiourea, $30 \mathrm{mM}$ Tris- $\mathrm{HCl}$ and $4 \%(\mathrm{w} / \mathrm{v})$ CHAPS, $\mathrm{pH} 8.5$, at a concentration of $5-10 \mathrm{mg} / \mathrm{ml}$ and labelled for DIGE analysis using fluorescent cyanine dyes according to the manufacturer's guidelines (GE Healthcare, Uppsala, Sweden). In brief, samples were labelled using Cy3 or Cy5 $\mathrm{N}$-hydroxysuccinamide ester DIGE dyes freshly dissolved in anhydrous dimethylformamide by mixing $50 \mu \mathrm{g}$ protein with $1 \mu$ l CyDye $(400 \mathrm{pmol} / \mu \mathrm{l})$. In addition, an internal standard generated by pooling all samples in the experiment was labelled with a third dye, Cy2. In each case, the labelling reaction was allowed to proceed on ice in the dark for $30 \mathrm{~min}$. The reaction was terminated by the addition of $10 \mathrm{nmol}$ lysine and subsequent incubation on ice in the dark for an additional 10 min. Each Cy3- and Cy5-labelled sample to be compared was then mixed with an aliquot of the Cy2-labelled internal standard, separated by 2D-PAGE as described below and scanned at three different wavelengths using a Typhoon 9400 variable mode imager (GE Healthcare) to generate Cy3-, Cy5and Cy2 images.

All gel images were imported into SameSpots software and passed an image QC test. Images corresponding to Cy2, Cy3 and Cy5 labelling were grouped and the best quality Cy2 gel image was used as a reference image. Automatic gel images alignment was applied first and adjusted by manual check. For each gel, 30 alignment vectors were applied to ensure the best match of candidate and reference images. Every single spot detected by the software was reviewed, and artefacts were excluded. The data generated by SameSpots was extracted as text file for further analysis (Yuan 2011).

The extracted data from the software package was normalized using the 'Subtract: Global loess: scale' approach in the Limma package (BioConductors-R http://www.r-project.org/). Data analysis followed the general protocol of the Limma package with some modifications adapted to this proteomic study.

\section{Protein identification}

Selected protein spots were cut from the gel, using the Investigator ProPic Automated 2D spot picker and digested with trypsin using the ProGest automated digestion unit (both from Perkin Elmer Life Sciences (UK) Ltd., Beaconsfield, England). The resulting peptides were analysed by mass spectrometry using a 4700 MALDI-TofTof mass spectrometer (Applied Biosystems, Foster City, CA, USA) to give a peptide mass fingerprint and peptide sequence information, which was searched against various databases using the Mascot search program (www.matrixscience.com) to identify the protein present in the gel spot.

\section{In silico analysis of parturition pathways}

To identify the biological pathways involved in human parturition, the set of proteins that changed during labour was mapped by GoMiner, using the whole genome as reference and limiting the analysis to the human database (Zeeberg et al. 2005). A further pathway analysis was carried out through the use of IPA (Ingenuity Systems, www.ingenuity. com). Four data sets (for each comparison) containing gene identifiers (from the DiGE analysis) and the corresponding expression values (fold change) were uploaded into the application. Each identifier was mapped to its corresponding object, providing a series of Network Eligible molecules. In the functional analysis, the biological functions that were most significant to the data sets were identified. Right-tailed Fisher's exact test was used to calculate a $P$ value determining the probability that each biological function assigned to that data set was due to chance alone.

We identified the canonical pathways that were most significant to the data set from the IPA library. The significance of the association between the data set and the canonical pathway was measured in two ways: i) by displaying a ratio of the number of molecules from the data set that map to the pathway divided by the total number of molecules that map to the canonical pathway. ii) Fisher's exact test was used to calculate a $P$ value determining the probability that the association between the genes in the data set and the canonical pathway could be explained by chance alone.

After function and canonical pathways analyses of all four data sets (SVD-NiL, IoL-NiL, SLEC-NiL and ILEC-NiL), we compared the pathway results in order to check any differences on the signalling process among the different modes of delivery.

\section{Western blotting}

Protein concentration was determined by the BCA assay. Plasma was diluted to give $50 \mu \mathrm{g}$ protein in $30 \mu \mathrm{l} 1 \times$ Laemmli buffer $(62.5 \mathrm{mM}$ Tris- $-\mathrm{HCl}, 2 \%(\mathrm{w} / \mathrm{v})$ SDS, $10 \% \quad(\mathrm{v} / \mathrm{v})$ glycerol, $0.01 \%(\mathrm{w} / \mathrm{v})$ bromophenol blue and $2.5 \%(\mathrm{v} / \mathrm{v})$ $\beta$-mercaptoethanol, $\mathrm{pH} 6.8$ ), heated to $100{ }^{\circ} \mathrm{C}$ for $5 \mathrm{~min}$ and proteins separated on $12 \%$ acrylamide Tris-glycine SDS-PAGE gels. Proteins were transferred to PVDF membranes by semidry blotting. Blocking, washing and antibody dilution buffers were from the WesternBreeze kit (Invitrogen). Membranes were blocked and then exposed to primary antibody overnight at $4{ }^{\circ} \mathrm{C}$. After washing, membranes were incubated with secondary antibodies for $2 \mathrm{~h}$ at room temperature, then washed and covered for $5 \mathrm{~min}$ with Immobilon Western Chemiluminescent HRP Substrate (Millipore, Billerica, MA, USA). 
Excess substrate was removed with blotting paper; membranes were enclosed in SaranWrap and exposed to Hyperfilm ECL (GE Healthcare) for between $1 \mathrm{~s}$ and $10 \mathrm{~min}$ before developing. Developed films were scanned on an Epson Perfection 3490 PHOTO flat-bed scanner and protein levels estimated by densitometry using ImageJ v1.37 software (NIH).

Primary antibodies and dilutions used were APOA4 (1:20 000, mouse monoclonal ab81616 (Abcam, Cambridge, UK)), APOE (1:10 000, mouse monoclonal (Santa Cruz Biotechnology, Santa Cruz, CA, USA)) and IgG $\gamma$ chain (1:5000, rabbit polyclonal ORCM 15 (Behring Diagnostics, Marburg, Germany)). Secondary (HRP conjugated) antibodies were goat anti-mouse (1:10 000, sc-2055 (Santa Cruz)) and goat anti-rabbit (1:5000, sc-2054 (Santa Cruz)).

Each plasma protein sample was run in duplicate, APO and IgG (as a loading control) proteins were quantitated and values for different blots were normalized to each other using the values of three samples that were loaded on each gel run. For individual lanes, APO/IgG ratios were calculated, then average ratios for each sample were determined and plotted. For intervillous plasma, SVD and NiL groups were compared using two-tailed, unpaired $t$-tests. For maternal plasma, preand in-labour groups were compared using two-tailed, paired $t$-tests.

\section{RIA}

In order to obtain more quantitative measurements, selected proteins (AFP, A1BG, APOE, LPOA, APOA1, APOB and hCG) were measured in maternal plasma by established RIA methods using specific antibodies (Doctors Laboratory, London http:// www.tdlpathology.com/).

\section{Supplementary data}

This is linked to the online version of the paper at http://dx.doi. org/10.1530/REP-12-0114.

\section{Declaration of interest}

The authors declare that there is no conflict of interest that could be perceived as prejudicing the impartiality of the research reported.

\section{Funding}

This work was supported Wellbeing of Women/Big Lottery Fund partnership (RG986). W Yuan held a PhD bursary from the SAFE network of Excellence (LSHB-CT-2004-503243).

\section{Acknowledgements}

The authors are grateful to Dr Kate O'Brian and Ms Alison Kirby for help with collection of maternal blood. They also thank $\mathrm{Dr}$ Wendy Heywood from the Institute of Child Health, University College London, for providing access to SameSpots Software.

\section{References}

Alexander HA, Sooranna SR, Myatt L \& Johnson MR 2012 Myometrial tumor necrosis factor- $\alpha$ receptors increase with gestation and labor and modulate gene expression through mitogen-activated kinase and nuclear factor-кB. Reproductive Sciences 19 43-54. (doi:10.1177/ 1933719111413297)

Anderson AB, Flint AP \& Turnbull AC 1975 Mechanism of action of glucocorticoids in induction of ovine parturition: effect on placental steroid metabolism. Journal of Endocrinology 66 61-70. (doi:10.1677/ joe.0.0660061)

Armendariz AD \& Krauss RM 2009 Hepatic nuclear factor $1-\alpha$ : inflammation, genetics, and atherosclerosis. Current Opinion in Lipidology 20 106-111. (doi:10.1097/MOL.0b013e3283295ee9)

Atkinson KR, Blumenstein M, Black MA, Wu SH, Kasabov N, Taylor RS, Cooper GJ \& North RA 2009 An altered pattern of circulating apolipoprotein E3 isoforms is implicated in preeclampsia. Journal of Lipid Research 50 71-80. (doi:10.1194/jlr.M800296-JLR200)

Beck S, Wojdyla D, Say L, Betran AP, Merialdi M, Requejo JH, Rubens C, Menon R \& Van Look PF 2010 The worldwide incidence of preterm birth: a systematic review of maternal mortality and morbidity. Bulletin of the World Health Organization 88 31-38. (doi:10.2471/BLT.08.062554)

de Beer FC, Baltz ML, Holford S, Feinstein A \& Pepys MB 1981 Fibronectin and C4-binding protein are selectively bound by aggregated amyloid $\mathrm{P}$ component. Journal of Experimental Medicine 154 1134-1139. (doi:10.1084/jem.154.4.1134)

Belo L, Gaffney D, Caslake M, Santos-Silva A, Pereira-Leite L, Quintanilha A \& Rebelo I 2004 Apolipoprotein E and cholesteryl ester transfer protein polymorphisms in normal and preeclamptic pregnancies. European Journal of Obstetrics, Gynecology, and Reproductive Biology 112 9-15. (doi:10.1016/S0301-2115(03)00240-9)

Breathnach SM, Bhogal B, de Beer FC, Melrose SM, Black MM \& Pepys MB 1983 Immunohistochemical studies of amyloid $P$ component and fibronectin in erythropoietic protoporphyria. British Journal of Dermatology 108 267-275. (doi:10.1111/j.1365-2133.1983.tb03964.x)

Bujold E, Romero R, Kusanovic JP, Erez O, Gotsch F, Chaiworapongsa T, Gomez R, Espinoza J, Vaisbuch E, Mee Kim Y et al. 2008 Proteomic profiling of amniotic fluid in preterm labor using two-dimensional liquid separation and mass spectrometry. Journal of Maternal-Fetal \& Neonatal Medicine 21 697-713. (doi:10.1080/14767050802053289)

Carter AM 2000 Placental oxygen consumption. Part I: in vivo studies - a review. Placenta 21 (Suppl A) S31-S37. (doi:10.1053/plac.1999.0513)

Casey ML, Cox SM, Beutler B, Milewich L \& MacDonald PC 1989 Cachectin/tumor necrosis factor- $\alpha$ formation in human decidua. Potential role of cytokines in infection-induced preterm labor. Journal of Clinical Investigation 83 430-436. (doi:10.1172/JCl113901)

Catalano RD, Lannagan TR, Gorowiec M, Denison FC, Norman JE \& Jabbour HN 2010 Prokineticins: novel mediators of inflammatory and contractile pathways at parturition? Molecular Human Reproduction 16 311-319. (doi:10.1093/molehr/gaq014)

Charnock-Jones DS 2002 Soluble flt-1 and the angiopoietins in the development and regulation of placental vasculature. Journal of Anatomy 200 607-615. (doi:10.1046/j.1469-7580.2002.00063.x)

Choi JW \& Pai SH 2000 Serum lipid concentrations change with serum alkaline phosphatase activity during pregnancy. Annals of Clinical and Laboratory Science 30 422-428.

Collazo MS, Porrata-Doria T, Flores I \& Acevedo SF 2012 Apolipoprotein E polymorphisms and spontaneous pregnancy loss in patients with endometriosis. Molecular Human Reproduction 18 372-377. (doi:10. 1093/molehr/gas004)

Conde-Agudelo A, Papageorghiou AT, Kennedy SH \& Villar J 2011 Novel biomarkers for the prediction of the spontaneous preterm birth phenotype: a systematic review and meta-analysis. BJOG: an International Journal of Obstetrics and Gynaecology 118 1042-1054. (doi:10.1111/j.1471-0528.2011.02923.x)

Csapo A 1956 Progesterone block. American Journal of Anatomy 98 273-291. (doi:10.1002/aja.1000980206)

DiScipio RG 1981 The binding of human complement proteins C5, factor B, $\beta 1 \mathrm{H}$ and properdin to complement fragment $\mathrm{C} 3 \mathrm{~b}$ on zymosan. Biochemical Journal 199 485-496.

DiScipio RG 1992 Ultrastructures and interactions of complement factors $\mathrm{H}$ and I. Journal of Immunology 149 2592-2599. 
Eeckhoute J, Formstecher P \& Laine B 2004 Hepatocyte nuclear factor $4 \alpha$ enhances the hepatocyte nuclear factor $1 \alpha$-mediated activation of transcription. Nucleic Acids Research 32 2586-2593. (doi:10.1093/ nar/gkh581)

Gautier-Stein A, Zitoun C, Lalli E, Mithieux G \& Rajas F 2006 Transcriptional regulation of the glucose-6-phosphatase gene by CAMP/vasoactive intestinal peptide in the intestine. Role of $\mathrm{HNF} 4 \alpha$, CREM, HNF1 $\alpha$, and C/EBP $\alpha$. Journal of Biological Chemistry 281 31268-31278. (doi:10.1074/jbc.M603258200)

Giussani DA, Winter JA, Jenkins SL, Tame JD, Abrams LM, Ding XY \& Nathanielsz PW 1998 Changes in fetal plasma corticotropin-releasing hormone during androstenedione-induced labor in the rhesus monkey: lack of an effect on the fetal hypothalamo-pituitary-adrenal axis. Endocrinology 139 2803-2810. (doi:10.1210/en.139.6.2803)

Goldberg M, Luknar-Gabor N, Keidar R \& Katz Y 2007 Synthesis of complement proteins in the human chorion is differentially regulated by cytokines. Molecular Immunology 44 1737-1742. (doi:10.1016/ j.molimm.2006.07.298)

Grace PA \& Mathie RT 1999 Ischaemia-Reperfusion Injury, pp 240-241. Oxford, UK: Blackwell Science.

Grammatopoulos DK \& Hillhouse EW 1999 Role of corticotropin-releasing hormone in onset of labour. Lancet 354 1546-1549. (doi:10.1016/ S0140-6736(99)03418-2)

Green PH, Glickman RM, Saudek CD, Blum CB \& Tall AR 1979 Human intestinal lipoproteins. Studies in chyluric subjects. Journal of Clinical Investigation 64 233-242. (doi:10.1172/JCI109444)

Hayashi H, Nutting DF, Fujimoto K, Cardelli JA, Black D \& Tso P 1990 Transport of lipid and apolipoproteins A-I and A-IV in intestinal lymph of the rat. Journal of Lipid Research 31 1613-1625.

Herbert SP, Odell AF, Ponnambalam S \& Walker JH 2007 The confluencedependent interaction of cytosolic phospholipase A2-alpha with annexin A1 regulates endothelial cell prostaglandin E2 generation. Journal of Biological Chemistry 282 34468-34478.

Hertelendy F, Romero R, Molnar M, Todd H \& Baldassare JJ 1993 Cytokineinitiated signal transduction in human myometrial cells. American Journal of Reproductive Immunology 30 49-57.

Hills FA, Gunn LK, Hardiman P, Thamaratnam S \& Chard T 1996 IGFBP-1 in the placenta, membranes and fetal circulation: levels at term and preterm delivery. Early Human Development 44 71-76. (doi:10.1016/ 0378-3782(95)01694-5)

Houser BL, Tilburgs T, Hill J, Nicotra ML \& Strominger JL 2011 Two unique human decidual macrophage populations. Journal of Immunology $\mathbf{1 8 6}$ 2633-2642. (doi:10.4049/jimmunol.1003153)

Hussain MM, Maxfield FR, Más-Oliva J, Tabas I, Ji ZS, Innerarity TL \& Mahley RW 1991 Clearance of chylomicron remnants by the low density lipoprotein receptor-related protein/ $\alpha$ 2-macroglobulin receptor. Journal of Biological Chemistry 266 13936-13940.

Iams JD, Romero R, Culhane JF \& Goldenberg RL 2008 Primary, secondary, and tertiary interventions to reduce the morbidity and mortality of preterm birth. Lancet 371 164-175. (doi:10.1016/S0140-6736(08) 60108-7)

Jauniaux E, Kiserud T, Ozturk O, West D \& Hanson MA 2000 Amniotic gas values and acid-base status during acute maternal hyperoxemia and hypoxemia in the early fetal sheep. American Journal of Obstetrics and Gynecology 182 661-665. (doi:10.1067/mob.2000.103937)

Karamessinis PM, Malamitsi-Puchner A, Boutsikou T, Makridakis M, Vougas K, Fountoulakis M, Vlahou A \& Chrousos G 2008 Marked defects in the expression and glycosylation of $\alpha 2-\mathrm{HS}$ glycoprotein/ fetuin-A in plasma from neonates with intrauterine growth restriction: proteomics screening and potential clinical implications. Molecular \& Cellular Proteomics 7 591-599. (doi:10.1074/mcp.M700422-MCP200)

Keelan JA, Coleman M \& Mitchell MD 1997 The molecular mechanisms of term and preterm labor: recent progress and clinical implications. Clinical Obstetrics and Gynecology 40 460-478. (doi:10.1097/ 00003081-199709000-00004)

Keelan JA, Blumenstein M, Helliwell RJ, Sato TA, Marvin KW \& Mitchell MD 2003 Cytokines, prostaglandins and parturition - a review. Placenta 24 (Suppl A) S33-S46. (doi:10.1053/plac.2002.0948)

Kekki M, Kurki T, Karkkainen T, Hiilesmaa V, Paavonen J \& Rutanen EM 2001 Insulin-like growth factor-binding protein-1 in cervical secretion as a predictor of preterm delivery. Acta Obstetricia et Gynecologica Scandinavica 80 546-551. (doi:10.1080/j.1600-0412.2001.080006546.x)
Kim MS, Gu BH, Song S, Choi BC, Cha DH \& Baek KH 2011 ITI-H4, as a biomarker in the serum of recurrent pregnancy loss (RPL) patients. Molecular BioSystems 7 1430-1440. (doi:10.1039/c0mb00219d)

Kristensen K, Wide-Swensson D, Schmidt C, Blirup-Jensen S, Lindström V, Strevens H \& Grubb A 2007 Cystatin C $\beta$-2-microglobulin and $\beta$-trace protein in pre-eclampsia. Acta Obstetricia et Gynecologica Scandinavica 86 921-926. (doi:10.1080/00016340701318133)

Lee DC, Romero R, Kim CJ, Chaiworapongsa T, Tarca AL, Lee J, Suh YL, Mazaki-Tovi S, Vaisbuch E, Mittal P et al. 2010 Surfactant protein-A as an anti-inflammatory component in the amnion: implications for human pregnancy. Journal of Immunology 184 6479-6491. (doi:10.4049/ jimmunol.0903867)

Liggins GC 1979 Initiation of parturition. British Medical Bulletin 35 145-150.

Lim LH \& Pervaiz S 2007 Annexin 1: the new face of an old molecule. FASEB Journal 21 968-975. (doi:10.1096/fj.06-7464rev)

López Bernal A 2003 Mechanisms of labour - biochemical aspects. BJOG: an International Journal of Obstetrics and Gynaecology 110 (Suppl 20) 39-45.

López Bernal A 2007 Overview. Preterm labour: mechanisms and management. BMC Pregnancy and Childbirth 7 (Suppl 1) S2. (doi:10.1186/1471-2393-7-S1-S2)

López Bernal A, Hansell DJ, Khong TY, Keeling JW \& Turnbull AC 1989 Prostaglandin E production by the fetal membranes in unexplained preterm labour and preterm labour associated with chorioamnionitis. British Journal of Obstetrics and Gynaecology 96 1133-1139. (doi:10.1111/j.1471-0528.1989.tb03187.x)

Magee TR, Cai Y, El-Houseini ME, Locker J \& Wan YJ 1998 Retinoic acid mediates down-regulation of the $\alpha$-fetoprotein gene through decreased expression of hepatocyte nuclear factors. Journal of Biological Chemistry 273 30024-30032. (doi:10.1074/jbc.273.45.30024)

Marchini G, Hagenäs L, Kocoska-Maras L, Berggren V \& Hansson LO 2005 Insulin-like growth factor binding protein-1 and interleukin-6 are markers of fetal stress during parturition at term gestation. Journal of Pediatric Endocrinology \& Metabolism 18 777-783. (doi:10.1515/JPEM. 2005.18.8.777)

Maul H, Maner WL, Saade GR \& Garfield RE 2003 The physiology of uterine contractions. Clinics in Perinatology 30 665-676. (doi:10.1016/ S0095-5108(03)00105-2)

McGladdery SH \& Frohlich JJ 2001 Lipoprotein lipase and apoE polymorphisms: relationship to hypertriglyceridemia during pregnancy. Journal of Lipid Research 42 1905-1912.

McLean M, Bisits A, Davies J, Woods R, Lowry P \& Smith R 1995 A placental clock controlling the length of human pregnancy. Nature Medicine 1 460-463. (doi:10.1038/nm0595-460)

Mecenas CA, Giussani DA, Owiny JR, Jenkins SL, Wu WX, Honnebier BO, Lockwood CJ, Kong L, Guller S \& Nathanielsz PW 1996 Production of premature delivery in pregnant rhesus monkeys by androstenedione infusion. Nature Medicine 2 443-448. (doi:10.1038/nm0496-443)

Mendel DB, Hansen LP, Graves MK, Conley PB \& Crabtree GR 1991 HNF- $1 \alpha$ and HNF-1 $\beta$ (vHNF-1) share dimerization and homeo domains, but not activation domains, and form heterodimers in vitro. Genes and Development 5 1042-1056. (doi:10.1101/gad.5.6.1042)

Mitchell BF \& Taggart MJ 2009 Are animal models relevant to key aspects of human parturition? American Journal of Physiology. Regulatory, Integrative and Comparative Physiology 297 R525-R545. (doi:10.1152/ ajpregu.00153.2009)

Miyamura K, Malhotra R, Hoppe HJ, Reid KB, Phizackerley PJ, Macpherson P \& Lopez Bernal A 1994 Surfactant proteins A (SP-A) and D (SP-D): levels in human amniotic fluid and localization in the fetal membranes. Biochimica et Biophysica Acta 1210 303-307. (doi:10.1016/0005-2760(94)90233-X)

Molvarec A, Kalabay L, Derzsy Z, Szarka A, Halmos A, Stenczer B, Arnaud P, Karadi I, Prohaszka Z \& Rigo J Jr 2009 Preeclampsia is associated with decreased serum $\alpha(2)-\mathrm{HS}$ glycoprotein (fetuin-A) concentration. Hypertension Research 32 665-669. (doi:10.1038/hr. 2009.79)

Mosialou I, Krasagakis K \& Kardassis D 2011 Opposite regulation of the human apolipoprotein $M$ gene by hepatocyte nuclear factor 1 and Jun transcription factors. Journal of Biological Chemistry 286 17259-17269. (doi:10.1074/jbc.M110.200659) 
Ndikum-Moffor FM, Simmen RC, Fields PA, Katoh N, Oikawa S, Buhi WC, Rollyson MK, Chang SM \& Fields MJ 1997 Synthesis and messenger ribonucleic acid expression of apolipoproteins $\mathrm{E}$ and $\mathrm{A}-\mathrm{I}$ by the bovine corpus luteum during the estrous cycle and pregnancy. Biology of Reproduction 56 745-756. (doi:10.1095/biolreprod56.3.745)

Odom DT, Zizlsperger N, Gordon DB, Bell GW, Rinaldi NJ, Murray HL, Volkert TL, Schreiber J, Rolfe PA, Gifford DK et al. 2004 Control of pancreas and liver gene expression by HNF transcription factors. Science 303 1378-1381. (doi:10.1126/science.1089769)

Olesen AW, Westergaard JG \& Olsen J 2006 Prenatal risk indicators of a prolonged pregnancy. The Danish Birth Cohort 1998-2001. Acta Obstetricia et Gynecologica Scandinavica 85 1338-1341. (doi:10.1080/ 00016340600935508)

Pepys MB \& Baltz ML 1983 Acute phase proteins with special reference to C-reactive protein and related proteins (pentaxins) and serum amyloid A protein. Advance Immunology 34 141-212.

Pereira L, Reddy AP, Jacob T, Thomas A, Schneider KA, Dasari S, Lapidus JA, Lu X, Rodland M, Roberts CT Jr et al. 2007 Identification of novel protein biomarkers of preterm birth in human cervical-vaginal fluid. Journal of Proteome Research 6 1269-1276. (doi:10.1021/ pr0605421)

Plunkett BA, Fitchev P, Doll JA, Gerber SE, Cornwell M, Greenstein EP \& Crawford SE 2008 Decreased expression of pigment epithelium derived factor (PEDF), an inhibitor of angiogenesis, in placentas of unexplained stillbirths. Reproductive Biology 8 107-120.

Price SA \& Lopez Bernal A 2001 Uterine quiescence: the role of cyclic AMP. Experimental Physiology 86 265-272. (doi:10.1113/eph8602182)

Qureshi IA, Xi XR, Limbu YR, Bin HY \& Chen MI 1999 Hyperlipidaemia during normal pregnancy, parturition and lactation. Annals of the Academy of Medicine of Singapore 28 217-221.

Rodriguez-Trejo A, Ortiz-Lopez MG, Zambrano E, Granados-Silvestre Mde L, Mendez C, Blondeau B, Breant B, Nathanielsz PW \& Menjivar M 2012 Developmental programming of neonatal pancreatic $\beta$-cells by a maternal low-protein diet in rats involves a switch from proliferation to differentiation. American Journal of Physiology. Endocrinology and Metabolism 302 E1431-E1439. (doi:10.1152/ajpendo.00619.2011)

Ruscheinsky M, De la Motte C \& Mahendroo M 2008 Hyaluronan and its binding proteins during cervical ripening and parturition: dynamic changes in size, distribution and temporal sequence. Matrix Biology 27 487-497. (doi:10.1016/j.matbio.2008.01.010)

Scholl PF, Cole RN, Ruczinski I, Gucek M, Diez R, Rennie A, Nathasingh C, Schulze K, Christian P, Yager JD et al. 2012 Maternal serum proteome changes between the first and third trimester of pregnancy in rural southern Nepal. Placenta 33 424-432. (doi:10.1016/j.placenta.2012.02. 009)

Sekiya A, Okano-Kosugi H, Yamazaki CM \& Koide T 2011 Pigment epithelium-derived factor (PEDF) shares binding sites in collagen with heparin/heparan sulfate proteoglycans. Journal of Biological Chemistry 286 26364-26374. (doi:10.1074/jbc.M111.252684)

Shaat N \& Groop L 2007 Genetics of gestational diabetes mellitus. Current Medicinal Chemistry 14 569-583. (doi:10.2174/092986707780059643)

Shintani Y, Nishimura J, Niiro N, Hirano K, Nakano H \& Kanaide H 2000 Mechanisms underlying the neurokinin A-induced contraction of the pregnant rat myometrium. British Journal of Pharmacology 130 1165-1173. (doi:10.1038/sj.bjp.0703410)

Slattery MM \& Morrison JJ 2002 Preterm delivery. Lancet 360 1489-1497. (doi:10.1016/S0140-6736(02)11476-0)

Smith GC 2001 Life-table analysis of the risk of perinatal death at term and post term in singleton pregnancies. American Journal of Obstetrics and Gynecology 184 489-496. (doi:10.1067/mob.2001.109735)

Smith R 2007 Parturition. New England Journal of Medicine 356 271-283. (doi:10.1056/NEJMra061360)
Soothill PW, Nicolaides KH, Rodeck CH \& Campbell S 1986 Effect of gestational age on fetal and intervillous blood gas and acid-base values in human pregnancy. Fetal Therapy 1 168-175. (doi:10.1159/ 000262264)

Tang B \& Gurpide E 1993 Direct effect of gonadotropins on decidualization of human endometrial stroma cells. Journal of Steroid Biochemistry and Molecular Biology 47 115-121. (doi:10.1016/0960-0760(93)90064-4)

Törnblom SA, Klimaviciute A, Byström B, Chromek M, Brauner A \& Ekman-Ordeberg G 2005 Non-infected preterm parturition is related to increased concentrations of IL-6, IL-8 and MCP-1 in human cervix. Reproductive Biology and Endocrinology 3 39. (doi:10.1186/14777827-3-39)

Vowinkel T, Mori M, Krieglstein CF, Russell J, Saijo F, Bharwani S, Turnage RH, Davidson WS, Tso P, Granger DN et al. 2004 Apolipoprotein A-IV inhibits experimental colitis. Journal of Clinical Investigation 114 260-269. (doi:10.1172/JCI21233)

Warner MM, Guo J \& Zhao Y 2001 The relationship between plasma apolipoprotein A-IV levels and coronary heart disease. Chinese Medical Journal 114 275-279.

Wei SQ, Fraser W \& Luo ZC 2010 Inflammatory cytokines and spontaneous preterm birth in asymptomatic women: a systematic review. Obstetrics and Gynecology 116 393-401. (doi:10.1097/AOG.0b013e3181e6dbc0)

Whaley K \& Ruddy S 1976 Modulation of C3b hemolytic activity by a plasma protein distinct from C3b inactivator. Science 193 1011-1013. (doi:10.1126/science.948757)

Wieslander CK, Marinis SI, Drewes PG, Keller PW, Acevedo JF \& Word RA 2008 Regulation of elastolytic proteases in the mouse vagina during pregnancy, parturition, and puerperium. Biology of Reproduction $\mathbf{7 8}$ 521-528. (doi:10.1095/biolreprod.107.063024)

Wong WM, Gerry AB, Putt W, Roberts JL, Weinberg RB, Humphries SE, Leake DS \& Talmud PJ 2007 Common variants of apolipoprotein A-IV differ in their ability to inhibit low density lipoprotein oxidation. Atherosclerosis 192 266-274. (doi:10.1016/j.atherosclerosis. 2006.07.017)

Yuan W 2011 Approaches for identifying blood-borne biomarkers of relevance for preterm labour. PhD Thesis. University of Bristol.

Yuan W \& Lopez Bernal A 2007 Cyclic AMP signalling pathways in the regulation of uterine relaxation. BMC Pregnancy and Childbirth 7 (Suppl 1) S10. (doi:10.1186/1471-2393-7-S1-S10)

Zeeberg BR, Qin H, Narasimhan S, Sunshine M, Cao H, Kane DW, Reimers M, Stephens RM, Bryant D, Burt SK et al. 2005 HighThroughput GoMiner, an 'industrial-strength' integrative gene ontology tool for interpretation of multiple-microarray experiments, with application to studies of Common Variable Immune Deficiency (CVID). BMC Bioinformatics 6 168. (doi:10.1186/1471-2105-6-168)

Zhang HL, Wu J \& Zhu J 2010 The role of apolipoprotein E in GuillainBarre syndrome and experimental autoimmune neuritis. Journal of Biomedicine \& Biotechnology 2010357412.

Zhang W, Xu W \& Xiong S 2011 Macrophage differentiation and polarization via phosphatidylinositol 3-kinase/Akt-ERK signaling pathway conferred by serum amyloid P component. Journal of Immunology 187 1764-1777. (doi:10.4049/jimmunol.1002315)

Zheng C, Khoo C, Furtado J \& Sacks FM 2010 Apolipoprotein C-III and the metabolic basis for hypertriglyceridemia and the dense low-density lipoprotein phenotype. Circulation 121 1722-1734. (doi:10.1161/ CIRCULATIONAHA.109.875807)

Received 29 March 2012

First decision 23 May 2012

Accepted 1 August 2012 